\title{
Physicochemical, Nutritional, Organoleptic Characteristics and Food Applications of Four Mango (Mangifera indica) Varieties
}

\author{
Emy Njoh Ellong, Sandra Adenet*, Katia Rochefort \\ Pôle Agroalimentaire Régional de Martinique (P. A. R. M.), Lamentin, Martinique (F.W.I.), France \\ Email: adenet@parm.asso.fr
}

Received 21 January 2015; accepted 8 February 2015; published 12 February 2015

Copyright @ 2015 by authors and Scientific Research Publishing Inc.

This work is licensed under the Creative Commons Attribution International License (CC BY).

http://creativecommons.org/licenses/by/4.0/

c) (i) Open Access

\begin{abstract}
Physicochemical characteristics of four varieties of mango (Uulie, Bassignac, Green and Moussache) from Martinique (F.W.I.) were examined at three ripening stages. All ripening protocols studied showed an evolution in parameters between the harvesting and the expandable stage. Fruit and pulp firmness, starch and vitamin $\mathrm{C}$ contents decreased whereas pulp $\mathrm{pH}$ and carotenoids content increased. Only fruit size and polyphenols content were the same during the ripening. Bassignac and Julie varieties were richer in vitamin C, polyphenols and carotenoids. Moussache variety was the most energetic with important carbohydrates content. The Green variety differed significantly with a light-coloured pulp, low fruity odour and mango flavour, and a specific slightly sweet, very sour, bitter and astringent taste. Moussache and Bassignac varieties had a very sweet taste unlike the Julie variety with a specific slightly sweeter taste. Different processing methods were tested for each variety. Mangoes technological ability processing had been validated.
\end{abstract}

\section{Keywords}

Mango, Ripening Stage, Physicochemical Characteristics, Nutritional Composition, Fruit Processing

\section{Introduction}

Mango (Mangifera indica L.), belonging to the Anacardiaceae family, is widely found in tropical and subtropical regions. It is one of the most important commercial crops worldwide in terms of production, marketing and consumption. There are more than 500 wild mango varieties [1].

\footnotetext{
"Corresponding author.
}

How to cite this paper: Ellong, E.N., Adenet, S. and Rochefort, K. (2015) Physicochemical, Nutritional, Organoleptic Characteristics and Food Applications of Four Mango (Mangifera indica) Varieties. Food and Nutrition Sciences, 6, 242-253. 
Mango fruit are climacteric and ripen rapidly after harvest. Disease susceptibility, sensitivity to low storage temperatures (below $13^{\circ} \mathrm{C}$ ), and perishability due to ripening and softening limit the storage, handling and transport potential of the fruit [2]. Mango fruit are harvested commercially within a range of maturities including immature green (dark green, no shoulders, ripens with poor quality), mature green (lighter green, shoulders formed, ripens with acceptable quality) and ripe (fruit that show color breaking to red or orange-yellow, ripen with optimum quality) [2] [3]. External and internal quality is critical to consumer acceptability, and flavour is an important marketing consideration [4]. Concentration of flavour volatiles and flavour quality were affected by harvest maturity [5], and storage temperature [6].

Post-harvest treatment of the fruit is a major issue and there are a lot of conservation methods all around the world. In India, fruits are picked green and stored in ventilated rooms at $15^{\circ} \mathrm{C}-21^{\circ} \mathrm{C}$ for a week [1]. In Israel, the fruits are in ethylene for $24 \mathrm{~h}$, then stored 7 - 10 days to have a uniform colour [1]. Ripening can be done naturally or artificially, and this step leads the fruit to maturity before consumption or processing. Natural ripening consists in storing fruits 10 to 15 days in the shade of hay [7] or 4 days at $25^{\circ} \mathrm{C}$ [8]. The uniformity of ripening can be assessed by measuring texture, brix and palatability (ratio soluble dry extract/titratable acidity) [9]. Note that there is no direct correlation between the maturity of the fruit and the colour of the skin [10].

New knowledge about mango composition is relevant to rational development in Martinique and the exploittation of this fruit neglected by consumers. In this study, we report a comparison of four varieties in Martinique and an evaluation of fruit characteristics. It focuses on: 1) the fruit physicochemical characteristics at three ripening approaches, 2) a comparison of the morphological, physical and analytical characteristics of four mango varieties grown in Martinique, 3) and the technological ability of fruit processing.

\section{Materials and Methods}

\subsection{Mangoes Supply}

\subsubsection{Plant Material}

Four mango varieties were selected for this study: Julie, Bassignac, Green and Moussache. Julie variety is characterized by large size (about $10 \mathrm{~cm}$ long and $260 \mathrm{~g}$ ). The skin of the mango Julie is smooth, strong, green and orange to red. The kernel is large and flattened. The flesh is creamy, aromatic and orange. Bassignac variety is small (7.5 cm long). The skin is smooth, strong, and green to orange mottled with black. The kernel is large and flattened. The flesh is fibrous, aromatic and orange. Green and Moussache varieties have characteristics similar to those of Bassignac mango, but aromatic taste differs.

\subsubsection{Ripening Methods Study}

Thirty mature green, undamaged and healthy fruits were harvested by producers for each of the four varieties of mango. The standard for the maturity stage is the appearance of a yellow-orange slight tint outside the fruit. A second sample of thirty fruits was carried out and the study repeated once. Fruit ripening of Mangifera indica was monitored. Its morphology and composition at different ripening stage were studied. A set of physical parameters was measured on each mango (size, weight and texture). They were then peeled, and the core was removed. Physicochemical analyses were carried out ( $\mathrm{pH}$, brix, titratable acidity, texture and colour). The crushed pulp then packed in plastic bag, was stored at $-18^{\circ} \mathrm{C}$ for subsequent composition analysis (energy, fibre, starch, polyphenols, carotenoids and vitamin $\mathrm{C}$ contents).

\subsubsection{Processing Methods Study}

The supply was made from a producers' cooperative. Fruits were at the stage of consumption, ripe, undamaged, healthy and ready to be eaten. Technological impact of Mangifera indica was monitored. A set of physical parameters was measured on each process (weight and texture). Physicochemical analyses were carried out ( $\mathrm{pH}$, brix, titratable acidity, texture and colour). The crushed pulp then packed in plastic bag, was stored at $-18^{\circ} \mathrm{C}$ for subsequent composition analysis (energy, fibre, starch, polyphenols, carotenoids and vitamin $\mathrm{C}$ contents).

\subsection{Composition of Mangoes at Three Different Ripening Stage}

30 fruits per each variety were collected at the harvesting stage. Three ripening protocols were studied as described in [1]. For the natural ripening, fruits were stored in ambient temperature $\left(27^{\circ} \mathrm{C}-30^{\circ} \mathrm{C}\right)$ in a ventilated 
area with 0.75 - 0.78 relative humidity. For the accelerated ripening, fruits were stored during 24 hours in a ventilated airtight box wherein $150 \mu \mathrm{L} / \mathrm{L}$ of ethylene was injected. Fruits were then stored in ambient temperature $\left(27^{\circ} \mathrm{C}-30^{\circ} \mathrm{C}\right)$ in a ventilated area with $0.75-0.78$ relative humidity. For the controlled ripening, fruits were stored in controlled temperatures $\left(15^{\circ} \mathrm{C}-21^{\circ} \mathrm{C}\right)$ with $0.54-0.59$ relative humidity. Monitoring of ripening was carried out by analyzing five fruits every two days. A repeat sampling was performed for each ripening.

\subsection{Morphology and Composition of Mangoes}

All analyses were carried out in triplicate.

\subsubsection{Morphological and Physical Characterization of the Fresh Fruit}

The proximate analyses of fruit size were carried out using a caliper for fruit length and thickness and a precision balance for fruit weight (Shimadzu UW4200 HV).

Pell firmness was measured in Newton (N) with a LLOYD Instruments TA Plus texture analyser, using a piston $4 \mathrm{~mm}$ in diameter and a $30 \mathrm{~mm} / \mathrm{min}$ speed.

Colour of the peel was determined with a Minolta CR-200 chromameter using the 3 parameters (L*a*b) established by the International Commission on Illumination: "L" for lightness to distinguish light colours from dark colours, "a” used to classify red to green colours, and "b” used to classify yellow to blue colours.

\subsubsection{Physicochemical and Nutritional Characterization of the Pulp}

pH, titratable acidity (TA) and soluble dry extract (SDE). About $25 \mathrm{~g}$ of pulp was blended with about $250 \mathrm{~mL}$ deionised water for 30 min using a magnetic stirrer. The $\mathrm{pH}$ of the blended solution was determined at ambient temperature. The TA was then measured without filtration by titration with $\mathrm{NaOH} 4 \mathrm{~g} / \mathrm{L}$ to equivalence point. The result was calculated in grams of acid per $100 \mathrm{~g}$ of fresh matter (g/100g). The SDE was measured in the filtered solution, in $\mathrm{g} / 100 \mathrm{~g}$, and expressed as SDE per $100 \mathrm{~g}$ of fresh matter, using a refractometer (Bellingham, Stanley Ltd. RFM $340^{\mathrm{TM}}$ ) at $20^{\circ} \mathrm{C}$ (Huber $^{\mathrm{TM}}$ thermostat).

Palatability (SDE/TA) was obtained by ratio of SDE/TA used to estimate fruit taste: sweet for a value $>1$ or bitter for a value $<1$.

Pulp colour and firmness were measured following the same method as used for peel colour and firmness.

Dry matter content (DM). Pulp samples (2 g of crushed, homogenized pulp) were collected from each mango for DM determination in triplicate, using a ventilated oven at $70^{\circ} \mathrm{C}$ for 5 hours at reduced pressure $(-1$ bar).

Starch content. The starch content was measured using the the K-TSTA 11/05 Megazyme enzymatic kit. The samples were crushed defrosted pulp. The absorbance at $334 \mathrm{~nm}$, proportional to the amount of glucose released by the hydrolysis of starch, was read using a spectrophotometer (JENWAY 7305).

Polyphenols content. Total polyphenols were determined using Folin and Ciocalteu's method described in [11]. Only the measure of raw extracts was considered.

Total carotenoids. Samples (2 g of crushed, homogenized pulp) were mixed with $50 \mathrm{~mL}$ of a ternary solvent (hexane/ethanol/acetone 50/25/25) and agitated during 30 minutes. After filtration, the solvent was placed in a separatory funnel and washed three times with $25 \mathrm{~mL}$ of distilled water to remove ethanol and acetone. The absorbance at $450 \mathrm{~nm}$, corresponding to the 5 predominant carotenoid species (beta-carotene, zeaxanthin, lycopene, lutein, beta-cryptoxanthin), was determined using a spectrophotometer (JENWAY 7305).

Vitamin C was measured using the K-ASCO 11/05 Megazyme colorimetric kit. In the presence of an electron carrier and at $\mathrm{pH}$ 3.5, L-ascorbic acid in the sample reduces the tetrazolium salt to a formazan compound, which is measured by the absorbance increase at $578 \mathrm{~nm}$. This absorbance at $578 \mathrm{~nm}$ was read using a spectrophotometer (JENWAY 7305).

Ash content. The mangoes ash content was calculated from a crushed sample $(1 \mathrm{~g})$ following heating to $525^{\circ} \mathrm{C}$ for $5 \mathrm{~h}$ as per the AOAC official method 923.03 (1996).

Lipid content. Lipids were extracted from the sample (2 g) after acid hydrolysis with $50 \mathrm{~mL}$ of $\mathrm{HCl} 288 \mathrm{~g} / \mathrm{L}$, at $80^{\circ} \mathrm{C}$. The mixture was filtered and rinsed with boiling water until neutral $\mathrm{pH}$. The filters were dried. The residues were placed in glass cartridges with $140 \mathrm{~mL}$ petroleum benzene and some pumice stones to extract the lipids in a Soxtherm extractor (Gerhardt Laboratory Systems, Königswinter, Germany). After extraction, the cartridges were oven dried at $101^{\circ} \mathrm{C}$.

Protein content. The protein content was determined through the quantification of total nitrogen using 
Kjeldahll's method. After mineralization of the sample (2 g) in $25 \mathrm{~mL}$ of $\mathrm{H}_{2} \mathrm{SO}_{4} 174.8 \mathrm{~g} / 100 \mathrm{~mL}$ in the presence of a catalyst in a Turbotherm mineralizator (Gerhardt Laboratory Systems, Königswinter, Germany). The mineralizate was distilled, in the presence of soda, in a Vapodest distiller (Gerhardt Laboratory Systems, Königswinter, Germany). The distillate was collected in $40 \mathrm{~mL}$ of boric acid $40 \mathrm{~g} \cdot \mathrm{L}^{-1}$ in the presence of some drops of Tashiro's indicator. The distillate was titrated by hydrochloric acid $\mathrm{HCl}(3.6 \mathrm{~g} / \mathrm{L})$.

Carbohydrate content. This was obtained by finding the difference (dry extract - (ash + lipids + proteins)). Carbohydrates represent the total fibre, starch and sugars content.

Energy value. Energy value was determined by adding lipid, carbohydrate and protein contents with this formula: $(19 \times$ Lipids $)+(4 \times$ Carbohydrates $)+(4 \times$ Proteins $)$. Energy value was expressed in $\mathrm{kcal} / 100 \mathrm{~g}$.

\subsubsection{Fruit Processing Methods}

For the three protocols, ripe fruits were cleaned and peeled.

Frozen cheeks. Mangoes were manually and longitudinally cut. Mango cheeks were retained, packed in plastic bag and frozen in a freezing fast cell ACFRI AR80 (core target temperature above $-18^{\circ} \mathrm{C}$ ).

Frozen puree. Mango pulp was manually cut into pieces and seeds removed.

The pieces were ground in STEPHAN vertical cutter at $1500 \mathrm{rpm}$ for $15 \mathrm{~min}$, packaged in $150 \mathrm{~mL}$ trays and frozen in a freezing fast cell ACFRI AR80 (core target temperature above $-18^{\circ} \mathrm{C}$ ).

Canned fruit. Mango cheeks were cut manually. Each cheek is then cut into strips.

Covering liquid was prepared by mixing water and cane sugar in an AURIOL cooking pot in order to have syrup at $20 \mathrm{~g} / 100 \mathrm{~g}$, and then heated to $75^{\circ} \mathrm{C}$. $4 / 4$ cans were filled with mango sticks (65 g/100g) and syrup (35 $\mathrm{g} / 100 \mathrm{~g})$. Cans were closed with a crimper BERTUZZI SPA A1 and sterilized in a STERIFLOW BARRIQUAND autoclave (sterilization schedule $20 \mathrm{~min}$ at $100^{\circ} \mathrm{C}$ ).

\subsection{Sensorial Analyses}

Selection of panel members started with twelve individuals, already qualified expert judges for fruit profile. Four 2-hour-specific mango training sessions were carried out until they were able to recognize and rate the aroma and flavour of four mango varieties according to the AFNOR 8586-1 and 8586-2 standards. Thirteen attributes represented the sensory profile according to AFNOR 13299 standard. Significant differences $(p<0.05)$ were found among the four varieties for eleven sensory attributes. Homogeneity in the group was also tested by twoway ANOVA for each attribute and the training was considered to be concluded when no panelists $\times$ samples interaction was found.

Analysis of variance (ANOVA) were done with FIZZ ${ }^{\circledR} 2005$ v1.0, UNIWIN Plus 2005 v6.1 and StatGraphics CENTURION $^{\circledR}$ XV 2005, software with a confidence interval of 5\%.

\subsection{Data Statistical Analysis}

The physical and chemical mean values of triplicate measurements or analysis were statistically analysed. Analysis of variance (ANOVA) based on Student Test, Principal Component Analysis (PCA) and Duncans multiple range test (DMRT) were performed using the software StatGraphics CENTURION ${ }^{\circledR}$ XV 2005 and Uniwin PLUS $^{\circledR} 2005$ v6.1.

\section{Results}

\subsection{Study of Three Ripening Methods on Mango Physicochemical Characteristics}

We compared the evolution of fruit characteristics according to the ripening approach. Three ripening protocols were studied for each mango variety. There were a natural ripening, a controlled ripening and an accelerated ripening. Two fruit production stages were studied, a commercial (harvesting stage with green fruit) and a consumption stage. The evaluation was on the consumption stage (ripe fruit). Quality criteria targeted was the assessment of firmness and fruit appearance, dry extract content higher than 15 - $19 \mathrm{~g} / 100 \mathrm{~g}$ and dry matter content exceeding $20 \mathrm{~g} / 100 \mathrm{~g}$.

We chose three parameters to compare their evolution according to the ripening protocols (fruit firmness, palatability and $\mathrm{pH}$ ). Table 1 shows the evolution of these parameters according to the ripening protocol and for the Moussache variety. The controlled ripening could extend the ripening. The palatability increase and the fruit 
Table 1. Evolution of fruit firmness, palatability and $\mathrm{pH}$ according to the ripening protocol for Moussache variety. Values for natural ripening, accelerated ripening and controlled ripening are indicated.

\begin{tabular}{cccccc}
\hline & & Fruit hardness & Pulp hardness & $\mathrm{pH}$ & \multicolumn{2}{c}{ Palatability } \\
\hline Ripening & Day & $\mathrm{kgF}$ & $\mathrm{kgF}$ & - & - \\
\hline Control & 0 & $6.63 \pm 0.11$ & $4.30 \pm 0.44$ & $4.23 \pm 0.25$ & $1.78 \pm 0.70$ \\
& 2 & $25.01 \pm 27.22$ & $3.03 \pm 0.61$ & $5.27 \pm 0.24$ & $15.20 \pm 5.83$ \\
Natural & 5 & $12.22 \pm 14.06$ & $0.11 \pm 0.05$ & $5.25 \pm 0.17$ & $12.67 \pm 4.50$ \\
& 2 & $16.18 \pm 18.51$ & $0.29 \pm 0.15$ & $4.32 \pm 0.47$ & $3.39 \pm 1.99$ \\
Accelerated & 5 & $12.35 \pm 13.81$ & $0.19 \pm 0.13$ & $5.11 \pm 0.01$ & $7.32 \pm 0.64$ \\
& 2 & $35.45 \pm 42.474$ & $3.17 \pm 1.47$ & $4.05 \pm 0.42$ & $1.25 \pm 0.71$ \\
& 5 & $22.85 \pm 27.56$ & $1.43 \pm 0.51$ & $4.22 \pm 0.17$ & $3.08 \pm 1.65$ \\
\hline
\end{tabular}

firmness decrease were slower. Results between the accelerated and the natural ripening were relatively close. There was a rapider evolution of the fruit two days after harvest compared with the natural ripening, ethylene effect sought, but this evolution slowed until the stage of consumption. Table 2 shows validated ripening times for different varieties depending on ripening protocols. The controlled ripening led to a period of ripening identical to the four varieties with a cycle of 7 - 8 days. The Bassignac variety had the longer time of ripening whatever the selected ripening. Julie and Green varieties had a similar ripening time. The Moussache variety had the shorter ripening cycle with 4 - 5 days.

All the ripening protocols showed the same modifications between the commercial and consumption stages (Table 3). There is no evolution in the fruits size. Fruits were harvested to the point of maturity. Fruits and pulp firmness decreased during the ripening. Pulp pH increased correlated with a decrease of titratable acidity and an increase in soluble dry extract. Fruit palatability, which is a quality feature for assessing the maturity of fruit, increased. Starch content decreased. Processing of this starch into reducing sugars led to the development of the fruit sweetness (total carbohydrate content did not change). The fruit at harvest stage was richer in vitamin $\mathrm{C}$ than the ripe fruit. Polyphenols content did not change between the two stages. This rate was about $100 \mathrm{mg} / 100 \mathrm{~g}$ depending on the variety studied, which positioned these varieties as plants rich in polyphenols. Ripe fruit was richer in total carotenoids content. This increase could be correlated with a change in the colour of the pulp, from a yellowish tint to a yellow-orange more or less intense depending on the variety.

\subsection{Physicochemical, Nutritional and Sensorial Characteristics of Four Mango Varieties}

\subsubsection{Physicochemical Characteristics}

Varietal characterisation determined physicochemical, nutritional and sensorial properties of four mango varieties. As previously, two production stages were studied, the commercial one (harvesting stage with ripe fruit) and the consumption one. Table 3 shows all these results and allowed to compare the four varieties studied. Bassignac variety was medium size fruit with a firm texture. Among the four varieties studied, it had the best quality in terms of nutrients of interest. It was a source of vitamin C, fibre and was rich in polyphenols. It also had the highest content of total carotenoids. The Green variety had a firm fibrous texture. Reduction in starch content during ripening was the most important in this variety. Palatability was lower for ripe fruit and close to 1 , so there was a balance between sweet and sour flavours. Nutritional quality was average. The fruit was a source of vitamin C and polyphenols and had very good fibre content. The Julie variety had a larger sized fruit. At the end of ripening, texture was firm and starch content was the highest within the group. This variety was very close to Bassignac in terms of nutrients of interest. It was a source of vitamin $\mathrm{C}$ and fibre, was rich in polyphenols and had a high carotenoid content. The Moussache mangoes had smaller oval shaped fruits with a softer texture. Palatability was highest in ripe fruit (sweeter and less acidic). This variety had lower nutritional contents (fibre, total polyphenols, vitamin C and total carotenoids). Nevertheless Moussache mangoes were the most energetic because of higher carbohydrate content. 
Table 2. Ripening times for mango varieties depending on the ripening protocols.

\begin{tabular}{cccc}
\hline & Natural ripening & Accelerated ripening & Controlled ripening \\
\hline Bassignac & $6-7$ days & $6-7$ days & 7 - 8 days \\
Green & 5 - 6 days & $5-6$ days & 7 - 8 days \\
Julie & 5 - 6 days & $5-6$ days & 7 - 8 days \\
Moussache & $4-5$ days & $4-5$ days & 7 - 8 days \\
\hline
\end{tabular}

Table 3. Physicochemical and nutritional analyses for mango varieties studied (a) in the commercial stage and (b) in the consumption stage.

(a) Commercial stage

\begin{tabular}{|c|c|c|c|c|c|c|c|c|c|c|c|c|c|c|c|}
\hline & 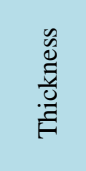 & 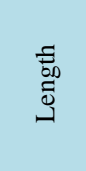 & $\begin{array}{l}\frac{E}{000} \\
\frac{0}{3} \\
3\end{array}$ & 売鴶 & 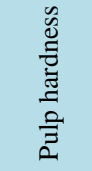 & के & $\stackrel{T}{a}$ & 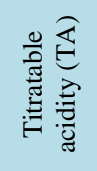 & 荘 & 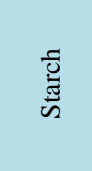 & 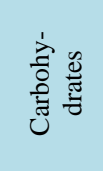 & $\stackrel{19}{>}$ & 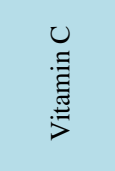 & 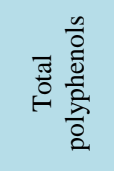 & 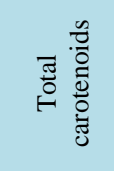 \\
\hline & $\mathrm{cm}$ & III & g & $\mathrm{kgF}$ & $g F$ & g/100g & - & $g$ & - & $\mathrm{g} / 100 \mathrm{~g}$ & $\mathrm{~g} / 100 \mathrm{~g}$ & $\mathrm{kcdl} / 100 \mathrm{~g}$ & gillo/luog & ing/ $100 \mathrm{~g}$ & $\mu \mathrm{g} / 100 \mathrm{~g}$ \\
\hline$B c$ & $\begin{array}{c}6.38 \pm \\
0.09\end{array}$ & $\begin{array}{c}7.80 \\
\pm 0.04\end{array}$ & & $\begin{array}{c}6.05 \pm \\
1.11\end{array}$ & $\begin{array}{c}3.28 \pm \\
2.50\end{array}$ & $\begin{array}{c}15.59 \pm \\
4.28\end{array}$ & $\begin{array}{c}3.52 \pm \\
0.08\end{array}$ & $\begin{array}{c}1.45 \pm \\
0.25\end{array}$ & $\begin{array}{c}0.75 \pm \\
0.08\end{array}$ & $\begin{array}{c}5.50 \\
\pm 2.12\end{array}$ & & & & & $\begin{array}{l}3.00 \\
2.05\end{array}$ \\
\hline Green & $\begin{array}{c}9.15 \\
0.80\end{array}$ & & $\begin{array}{l}202.20 \\
\pm 36.03\end{array}$ & $\begin{array}{c}8.07 \pm \\
0.12\end{array}$ & $\begin{array}{c}5.22 \pm \\
0.74\end{array}$ & $\begin{array}{c}6.55 \pm \\
1.10\end{array}$ & $\begin{array}{c}3.58 \pm \\
0.24\end{array}$ & $\begin{array}{c}1.62 \pm \\
0.27\end{array}$ & $\begin{array}{c}0.28 \pm \\
0.00\end{array}$ & $\begin{array}{c}6.55 \\
\pm 0.58\end{array}$ & & & & & \\
\hline Julie & $\begin{array}{r}7.53 \\
1.12\end{array}$ & 9.69 & $\begin{array}{l}300.35 \\
\pm 9.59\end{array}$ & $\begin{array}{c}43.77 \pm \\
50.67\end{array}$ & $\begin{array}{c}6.52 \pm \\
1.02\end{array}$ & $\begin{array}{c}9.14 \pm \\
0.88\end{array}$ & $\begin{array}{c}3.09 \pm \\
0.13\end{array}$ & $\begin{array}{c}1.39 \pm \\
0.23\end{array}$ & $\begin{array}{c}0.47 \pm \\
0.12\end{array}$ & $\begin{array}{c}7.50 \\
\pm 2.12\end{array}$ & $\begin{array}{c}48.42 \\
\pm 38.97\end{array}$ & 19 & & $\begin{array}{l}50 \\
37\end{array}$ & $\begin{array}{l}954.00 \\
\pm 52.33\end{array}$ \\
\hline oussache & $\begin{array}{r}7.98 \\
0.85\end{array}$ & $\begin{array}{c}5.88 \\
\pm 0.49\end{array}$ & $\begin{array}{r}145.15 \\
\pm 44.65\end{array}$ & $\begin{array}{c}6.63 \pm \\
0.11\end{array}$ & $\begin{array}{c}4.30 \pm \\
0.44\end{array}$ & $\begin{array}{c}10.10 \pm \\
0.59\end{array}$ & $\begin{array}{c}4.23 \pm \\
0.25\end{array}$ & $\begin{array}{c}0.42 \pm \\
0.14\end{array}$ & $\begin{array}{c}1.79 \pm \\
0.70\end{array}$ & $\begin{array}{r}12.90 \\
\pm 3.28\end{array}$ & $\begin{array}{r}23.53 \\
\pm 2.71\end{array}$ & $\begin{array}{r}105.95 \\
\pm 16.90\end{array}$ & $\begin{array}{r}30.85 \\
\pm 1.06\end{array}$ & $\begin{array}{c}57.00 \\
\pm 20.00\end{array}$ & $\begin{array}{c}449.33 \\
\pm 633.11\end{array}$ \\
\hline
\end{tabular}

(b) Consomption stage

\begin{tabular}{|c|c|c|c|c|c|c|c|c|c|c|c|c|}
\hline & 苨总 & 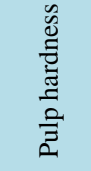 & के & 壳 & 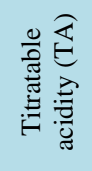 & $\begin{array}{l}\frac{5}{5} \\
\text { 窐 }\end{array}$ & 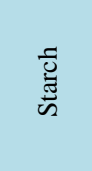 & 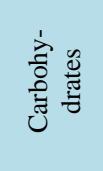 & $\stackrel{5}{>}$ & 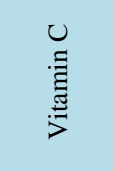 & 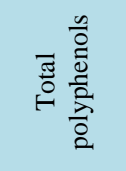 & 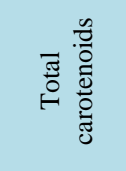 \\
\hline Units & $\mathrm{kgF}$ & $\mathrm{kgF}$ & $\mathrm{g} / 100 \mathrm{~g}$ & - & $\mathrm{g} / 100 \mathrm{~g}$ & - & $\mathrm{g} / 100 \mathrm{~g}$ & $\mathrm{~g} / 100 \mathrm{~g}$ & $\mathrm{kcal} / 100 \mathrm{~g}$ & $\mathrm{mg} / 100 \mathrm{~g}$ & mg/100g & $\mu \mathrm{g} / 100 \mathrm{~g}$ \\
\hline Bassignac & $\begin{array}{c}21.94 \pm \\
2.02\end{array}$ & $\begin{array}{c}0.25 \pm \\
0.12\end{array}$ & $\begin{array}{c}21.89 \pm \\
0.20\end{array}$ & $\begin{array}{c}4.13 \pm \\
0.44\end{array}$ & $\begin{array}{c}0.86 \pm \\
0.38\end{array}$ & $\begin{array}{l}1.97 \pm \\
0.85\end{array}$ & $\begin{array}{c}4.50 \pm \\
2.12\end{array}$ & $\begin{array}{c}20.31 \pm \\
0.00\end{array}$ & \pm & \pm & $\begin{array}{c}100.18 \pm \\
6.12\end{array}$ & $\begin{array}{c}4138.50 \pm \\
1686.45\end{array}$ \\
\hline Green & $\begin{array}{c}11.70 \pm \\
13.26\end{array}$ & $\begin{array}{c}0.18 \pm \\
0.11\end{array}$ & $\begin{array}{c}15.48 \pm \\
1.32\end{array}$ & $\begin{array}{c}4.45 \pm \\
0.42\end{array}$ & $\begin{array}{c}0.70 \pm \\
0.37\end{array}$ & $\begin{array}{c}1.83 \pm \\
1.10\end{array}$ & $\begin{array}{c}0.60 \pm \\
0.44\end{array}$ & $\begin{array}{c}14.33 \pm \\
2.40\end{array}$ & $\begin{array}{c}66.15 \pm \\
6.15\end{array}$ & $\begin{array}{c}17.05 \pm \\
11.53\end{array}$ & $\begin{array}{c}79.10 \pm \\
8.49\end{array}$ & $\begin{array}{c}805.13 \pm \\
1135.44\end{array}$ \\
\hline Julie & $\begin{array}{c}9.30 \pm \\
11.00\end{array}$ & $\begin{array}{c}0.15 \pm \\
0.03\end{array}$ & $\begin{array}{c}20.19 \pm \\
1.87\end{array}$ & $\begin{array}{c}4.30 \pm \\
0.18\end{array}$ & $\begin{array}{c}0.47 \pm \\
0.16\end{array}$ & $\begin{array}{c}3.26 \pm \\
1.37\end{array}$ & $\begin{array}{c}6.00 \pm \\
0.00\end{array}$ & $\begin{array}{c}21.48 \pm \\
0.02\end{array}$ & $\begin{array}{c}91.60 \pm \\
8.49\end{array}$ & $\begin{array}{c}14.50 \pm \\
2.12\end{array}$ & $\begin{array}{c}111.81 \pm \\
9.21\end{array}$ & $\begin{array}{c}3647.50 \pm \\
152.03\end{array}$ \\
\hline Moussache & $\begin{array}{c}12.22 \pm \\
14.07\end{array}$ & $\begin{array}{c}0.11 \pm \\
0.05\end{array}$ & $\begin{array}{c}22.81 \pm \\
1.39\end{array}$ & $\begin{array}{c}5.25 \pm \\
0.17\end{array}$ & $\begin{array}{c}0.13 \pm \\
0.04\end{array}$ & $\begin{array}{c}12.67 \pm \\
4.52\end{array}$ & $\begin{array}{c}3.27 \pm \\
0.72\end{array}$ & $\begin{array}{c}23.99 \pm \\
1.61\end{array}$ & $\begin{array}{c}107.10 \pm \\
11.17\end{array}$ & $\begin{array}{c}6.85 \pm \\
0.21\end{array}$ & $\begin{array}{c}66.13 \pm \\
18.56\end{array}$ & $\begin{array}{c}603.35 \pm \\
850.87\end{array}$ \\
\hline Average & $\begin{array}{c}13.79 \pm \\
5.58\end{array}$ & $\begin{array}{c}0.17 \pm \\
0.06\end{array}$ & $\begin{array}{c}20.09 \pm \\
3.26\end{array}$ & $\begin{array}{c}4.53 \pm \\
0.50\end{array}$ & $\begin{array}{c}0.54 \pm \\
0.32\end{array}$ & $\begin{array}{c}4.93 \pm \\
5.20\end{array}$ & $\begin{array}{c}3.59 \pm \\
2.29\end{array}$ & $\begin{array}{c}20.03 \pm \\
4.10\end{array}$ & $\begin{array}{c}88.21 \pm \\
16.88\end{array}$ & $\begin{array}{c}15.98 \pm \\
7.69\end{array}$ & $\begin{array}{c}89.31 \pm \\
20.54\end{array}$ & $\begin{array}{c}2298.62 \pm \\
1853.74\end{array}$ \\
\hline
\end{tabular}

\subsubsection{Sensorial Profiles of Studied Varieties}

Eleven parameters were chosen for this sensorial analysis: pulp colour differences, natural mango scent, fruity aromas, fermented odours, sweetness, sourness, bitterness, astringency, textures, juiciness and firmness. Using these specific parameters, this organoleptic analysis revealed significant characteristics differences, in the varieties studied. Table 1 outlines all the results. Green varieties significantly differed from the others by their lightcoloured flesh and indistinct mango aroma, a bitter-sweet tangy taste and a firm juicy mouthfeel. The Julie mango had a light-coloured pulp, an intense, but slightly fermented fruity mango aroma, a specific sweet bittersharp taste, and was extremely juicy with a firm texture. The Bassignac variety was characterized by deeper orange-coloured pulp, a strong fermented taste and smell, an intense fruity mango aroma with a sweet juicy taste, 
although hints of acidity and bitterness were observed. The mangoes were less firm than the Julie. Finally, the Moussache variety was defined by its light-coloured pulp, its aroma midway between fruity and fermented, an intense mango aroma and a slightly firm and very juicy texture. In general there is a strong correlation between the flesh colour of the fruits and their olfactory and aromatic intensities.

\subsection{Study of Different Processing Methods for Each Mango Variety}

The aim of this next part of the study was to evaluate the technological abilities to transform the four selected mango varieties. Different processing methods were tested. This transformation was evaluated and analyzed based on the following criteria: fruit size, production yield, physicochemical analysis, nutritional analysis and impact of the process on the raw material. Data in terms of size are summarized in Figure 1. These box plot

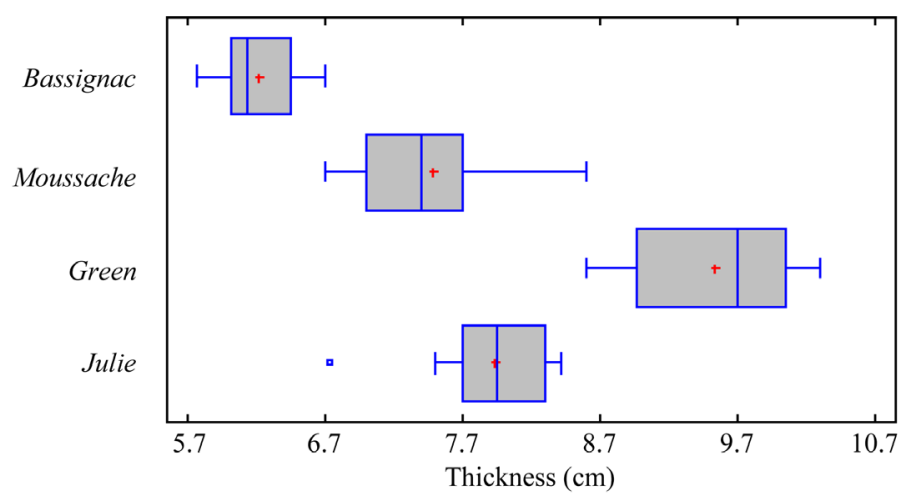

(a)

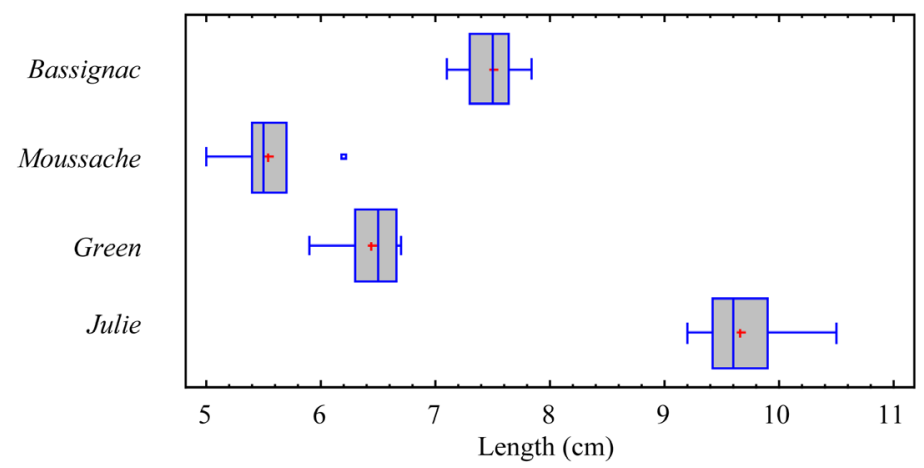

(b)

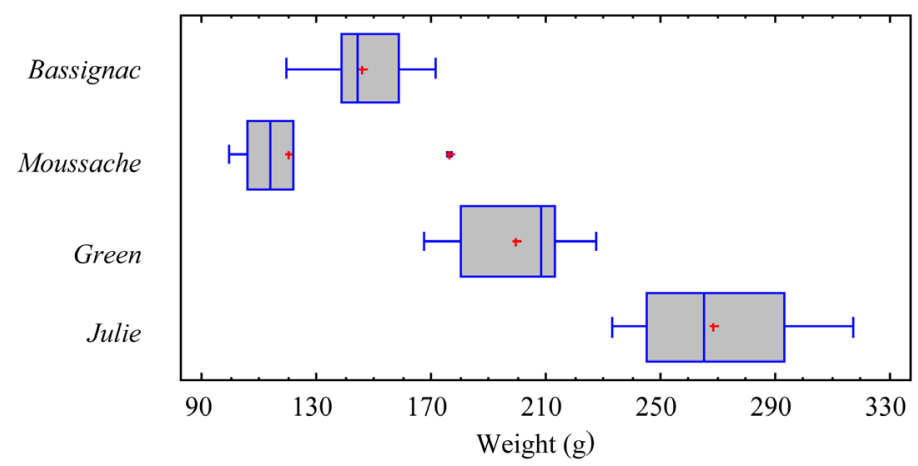

(c)

Figure 1. (a) Box plot representation of the thickness (in $\mathrm{cm}$ ) of fruit depending on the variety of mango studied; (b) Box plot representation of the length (in $\mathrm{cm}$ ) of the fruit depending on the variety of mango studied; (c) Box plot representation fruit weight (in g) depending on the variety of mango studied. 
representations allow quick and easy statistical analysis of the four varieties studied in terms of mean, median, minimum and maximum of values measured.

The Moussache variety had the smallest shape and Julie the largest (Figures 1(a)-(c)), in terms of thickness, length and weight. The principal component analysis of measured shapes can highlight four distinct groups in terms of size (Figure 2) corresponding to the four varieties. The Moussache variety differed from the other three varieties, with the smallest size and fruit more or less rounded (thicker than longer). The Julie variety also differed from the other three varieties, with the largest fruit size and thickness and length comparable. The Green variety was characterized by an average size and shape distinctly thicker than longer. The Bassignac mangoes were also average sized with a longer than thicker shape.

\subsubsection{Processing Ability in Frozen Cheeks}

Table 4 shows physicochemical and nutritional analysis of the mango frozen cheeks. The freezing process of the peeled cheeks mango gave a product of good appearance, with the original flesh colour being maintained, and freeze-homogeneous. This process preserved the nutritional potential of the fruit. Vitamin C content was unchanged from the fresh fruit. Thawing was tested to simulate the act of consumption. The complete cheek thawing was effective in less than 6 hours at $4^{\circ} \mathrm{C}$. After thawing, there occurs a significant change in the texture and consistency of the cheeks for the four varieties (exudation). This is confirmed by the results of measurements on the cheeks before and after thawing (Table 5). This change in the texture was more important for Julie and Bassignac varieties with a significant loss in elasticity and hardness. For Moussache and Green varieties, cheek

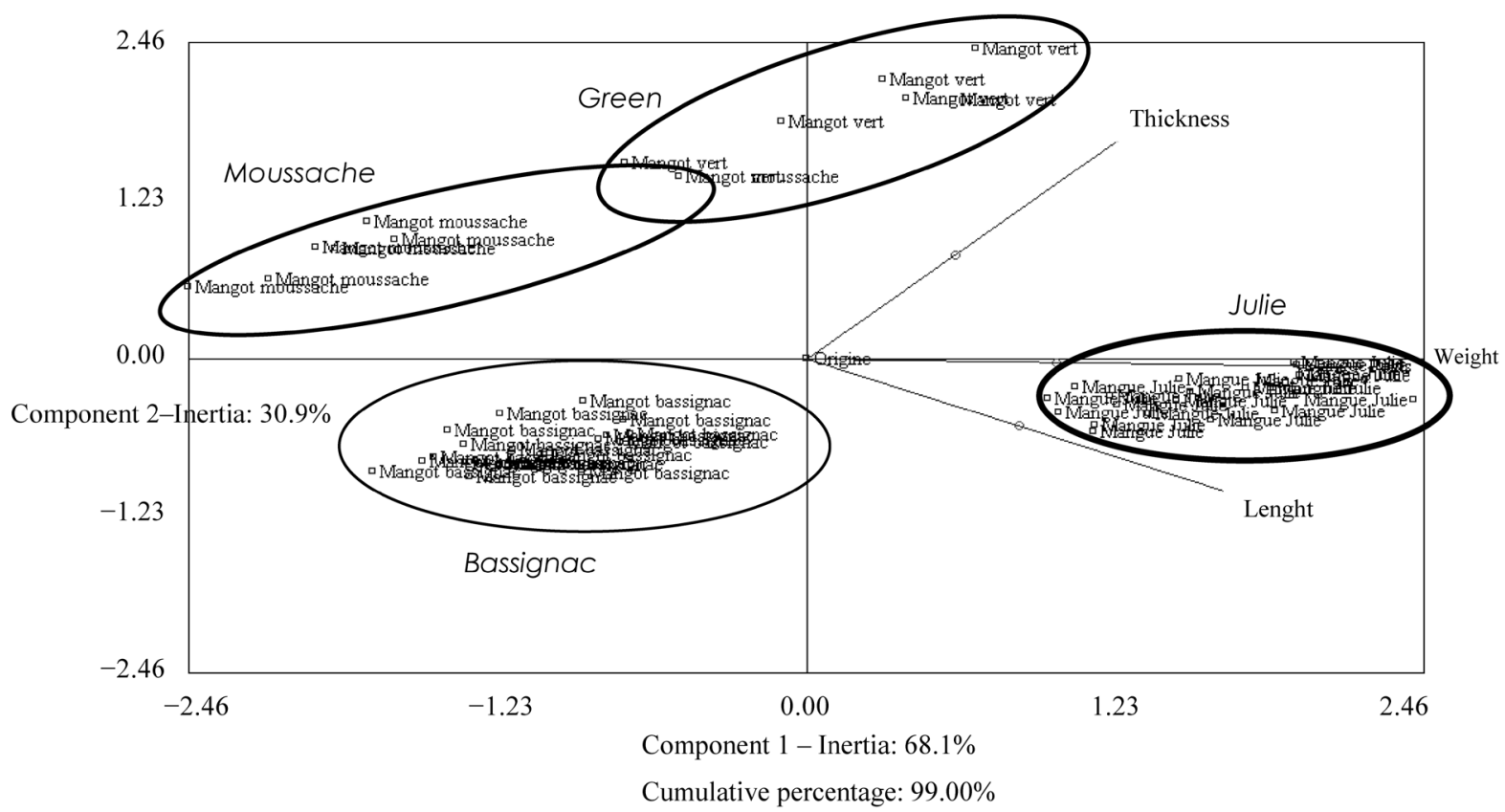

Figure 2. Principal component analysis of fruit size (thickness, length, weight) depending on the variety of mango studied.

Table 4. Different physicochemical and nutritional analysis of frozen cheek for each mango varieties.

\begin{tabular}{cccccccccc}
\hline & $\mathrm{pH}$ & $\mathrm{SDE}$ & $\begin{array}{c}\text { Titratable } \\
\text { acidity }\end{array}$ & Colour L & Colour a & Colour b & Dry matter & $\begin{array}{c}\text { Energy } \\
\text { value }\end{array}$ & $\begin{array}{c}\text { Vitamin C } \\
\text { Units }\end{array}$ \\
\hline Bassignac & $4.11 \pm 0.00$ & $18.29 \pm 0.00$ & $0.57 \pm 0.02$ & $62.52 \pm 0.12$ & $10.54 \pm 0.41$ & $52.89 \pm 0.18$ & $21.68 \pm 0.18$ & $87.1 \pm 1.2$ & $5.64 \pm 0.00$ \\
Green & $3.78 \pm 0.00$ & $17.23 \pm 0.00$ & $0.86 \pm 0.03$ & $69.65 \pm 0.05$ & $4.55 \pm 0.16$ & $54.15 \pm 0.12$ & $20.77 \pm 0.30$ & $82.4 \pm 1.2$ & $9.42 \pm 1.35$ \\
Julie & $4.70 \pm 0.00$ & $19.45 \pm 0.00$ & $0.25 \pm 0.01$ & $67.92 \pm 0.21$ & $10.37 \pm 0.01$ & $57.82 \pm 0.33$ & $24.09 \pm 0.06$ & $97.4 \pm 0.4$ & $31.14 \pm 0.00$ \\
Moussache & $4.49 \pm 0.00$ & $18.03 \pm 0.00$ & $0.38 \pm 0.07$ & $67.55 \pm 0.14$ & $1.40 \pm 0.01$ & $52.40 \pm 0.04$ & $21.73 \pm 0.06$ & $89.3 \pm 0.3$ & $24.29 \pm 0.00$ \\
\hline
\end{tabular}


Table 5. Evolution of the texture of mango cheeks before and after treatment: hardness (kgF), elasticity (mm) and chewiness $(\mathrm{kgF} \cdot \mathrm{mm})$.

\begin{tabular}{ccccccc}
\hline & \multicolumn{3}{c}{ Before freezing } & & \multicolumn{3}{c}{ After freezing/thawing } \\
& Hardness & Elasticity & Chewiness & Hardness & Elasticity & Chewiness \\
\hline & $\mathrm{kgF}$ & $\mathrm{mm}$ & $\mathrm{kgF} \cdot \mathrm{mm}$ & $\mathrm{kgF}$ & $\mathrm{mm}$ & $\mathrm{kgF} \cdot \mathrm{mm}$ \\
\hline Moussache & $0.110 \pm 0.058$ & $0.509 \pm 0.104$ & $0.008 \pm 0.005$ & $0.094 \pm 0.056$ & $0.302 \pm 0.089$ & $0.004 \pm 0.001$ \\
Green & $0.234 \pm 0.095$ & $1.349 \pm 0.390$ & $0.085 \pm 0.059$ & $0.222 \pm 0.185$ & $1.140 \pm 1.047$ & $0.064 \pm 0.027$ \\
Julie & $0.439 \pm 0.124$ & $1.179 \pm 0.206$ & $0.047 \pm 0.015$ & $0.077 \pm 0.020$ & $0.225 \pm 0.198$ & $0.001 \pm 0.001$ \\
Bassignac & $0.859 \pm 0.003$ & $1.657 \pm 0.131$ & $0.143 \pm 0.254$ & $0.226 \pm 0.206$ & $0.934 \pm 1.026$ & $0.020 \pm 0.017$ \\
\hline
\end{tabular}

textures were particularly modified by a loss of elasticity. Sensorial analysis showed that end product presented significant changes in texture, taste and smell compared to fresh fruit. It had a soft texture, smell and tasted less intense.

\subsubsection{Processing Ability in Frozen Puree}

Table 6 shows physicochemical and nutritional analysis of the mango frozen puree. The process of transformation of frozen mango puree yielded a satisfactory appearance, smooth and consistent texture with maintaining the original colour and organoleptic characteristics of the product. This process preserved the nutritional potential of the fruit. Vitamin C content was unchanged from the fresh fruit. The texture of the puree was not changed after thawing. Significant differences in texture were observed between varieties (Table 6). Moussache and Green purees were relatively close in terms of texture. Mashed Bassignac was in an intermediate position. Julie puree was clearly distinguishable from other varieties and had a strong cohesion and high elasticity.

\subsubsection{Processing Ability in Canned Fruits in Syrup}

Table 7 shows physicochemical and nutritional analysis of the mango fruit in syrup. The transformation of mango fruits in syrup gave a satisfactory product in terms of aroma and flavour. The holding of mango slices was satisfactory, except for the Moussache variety (loss of pieces in syrup). The applied sterilization schedule provided stable canned (stability test in accordance). Significant losses in vitamin C were observed under the action of heat upon treatment in the autoclave. There was also an important Maillard reaction. Strong browning of slices compared to the initial raw material (fresh fruit) induced a change in the color that was darker and dull.

\section{Discussion}

This study first compared the evolution of fruit characteristics according to the ripening approach. Other studies have been conducted on the influence of the ripening on mangoes [12], but none to date varieties of Martinique. Some mangoes ripening methods are described in literature and allowed to control the ripening. We have chosen a controlled ripening and an accelerated one according to the literature. They are the most used in fruits and vegetables preservation for food industry. We noted that the controlled ripening extended the ripening period. This result was expected and consistent with what is already described. On the other hand, accelerated ripening gave similar results to the natural one. This result is unusual. The protocol for accelerated ripening provides a fruit exposure to ethylene for 24 hours. Given the results, it would be interesting to extend the exposure time or to increase the concentration of ethylene to optimize the acceleration of ripening.

We also proposed physicochemical and nutritional characteristics of four mango varieties present in Martinique (F.W.I.). The sensorial profile for each variety is also something new on the island. We observed lots of sampling constraints. Further studies could be considered in compliance with the sampling protocol established to standardize the harvesting and ripening conditions for the mango samples. This would consolidate the organoleptic characteristics identified in the four varieties of mango orchards present in Martinique. The nutritional quality of mangoes in Martinique is remarkable. Fruits are notably rich in total polyphenols, total carotenoids and vitamin C. In comparison with other fruits for the rate of polyphenols [13], Martinique mangoes would be at the sixth position with about $101.34 \mathrm{mg} / 100 \mathrm{~g}$. For total carotenoids, with about $2.4 \mathrm{mg} / 100 \mathrm{~g}$, mangoes are richer than apricots $(0.9 \mathrm{mg} / 100 \mathrm{~g})$ but nevertheless less rich than acaï $(5.1 \mathrm{mg} / 100 \mathrm{~g})$. These results are close than those 
Table 6. Physicochemical, nutritional and texture analysis of frozen puree for each mango varieties.

\begin{tabular}{|c|c|c|c|c|c|c|c|c|c|c|c|c|}
\hline & $\mathrm{pH}$ & SDE & $\begin{array}{c}\text { Titratable } \\
\text { acidity }\end{array}$ & & Colour & & $\begin{array}{c}\text { Dry } \\
\text { matter }\end{array}$ & $\begin{array}{l}\text { Energy } \\
\text { value }\end{array}$ & Vitamin C & Hardness & Elasticity & Chewiness \\
\hline & - & $\mathrm{g} / 100 \mathrm{~g}$ & $\mathrm{~g} / 100 \mathrm{~g}$ & $\mathrm{~L}$ & $\mathrm{a}$ & b & $\mathrm{g} / 100 \mathrm{~g}$ & $\mathrm{kcal} / 100 \mathrm{~g}$ & $\mathrm{mg} / 100 \mathrm{~g}$ & $\mathrm{kgF}$ & $\mathrm{mm}$ & $\mathrm{kgF} \cdot \mathrm{mm}$ \\
\hline Bassignac & $\begin{array}{c}4.21 \pm \\
0.00\end{array}$ & $\begin{array}{c}19.70 \pm \\
0.00\end{array}$ & $0.40 \pm 0.17$ & $\begin{array}{c}65.4 \pm \\
0.18\end{array}$ & $\begin{array}{c}6.53 \pm \\
0.04\end{array}$ & $\begin{array}{c}54.16 \pm \\
0.02\end{array}$ & $\begin{array}{c}22.60 \pm \\
0.04\end{array}$ & 93.1 & $\begin{array}{c}18.93 \pm \\
0.00\end{array}$ & $\begin{array}{c}2.228 \pm \\
0.076\end{array}$ & $\begin{array}{c}1.075 \pm \\
0.022\end{array}$ & $\begin{array}{l}1.200 \pm \\
0.197\end{array}$ \\
\hline Green & $\begin{array}{c}3.90 \pm \\
0.00\end{array}$ & $\begin{array}{c}17.62 \pm \\
0.00\end{array}$ & $0.93 \pm 0.00$ & $\begin{array}{c}69.76 \pm \\
0.12\end{array}$ & $\begin{array}{c}2.49 \pm \\
0.23\end{array}$ & $\begin{array}{c}54.39 \pm \\
0.04\end{array}$ & $\begin{array}{c}21.20 \pm \\
0.04\end{array}$ & $5 \pm 0.2$ & $\begin{array}{c}3.03 \pm \\
0.14\end{array}$ & $\begin{array}{l}1.948 \pm \\
0.078\end{array}$ & $\begin{array}{c}1.037 \pm \\
0.011\end{array}$ & $\begin{array}{l}1.265 \pm \\
0.078\end{array}$ \\
\hline Julie & $\begin{array}{c}4.41 \pm \\
0.00\end{array}$ & $\begin{array}{c}21.11 \pm \\
0.00\end{array}$ & $0.29 \pm 0.14$ & $\begin{array}{l}70.69 \pm \\
0.33\end{array}$ & $\begin{array}{c}7.63 \pm \\
0.01\end{array}$ & $\begin{array}{c}58.43 \pm \\
0.06\end{array}$ & $\begin{array}{c}26.32 \pm \\
0.02\end{array}$ & $\begin{array}{c}105.6 \pm \\
0.0\end{array}$ & $\begin{array}{c}30.40 \pm \\
0.00\end{array}$ & $\begin{array}{c}0.022 \pm \\
0.001\end{array}$ & $\begin{array}{c}12.36 \pm \\
1.144\end{array}$ & $\begin{array}{c}0.206 \pm \\
0.028\end{array}$ \\
\hline Moussache & $\begin{array}{c}4.39 \pm \\
0.00\end{array}$ & $\begin{array}{c}20.19 \pm \\
0.00\end{array}$ & $0.32 \pm 0$ & $\begin{array}{c}69.09 \pm \\
0.03\end{array}$ & $\begin{array}{c}2.17 \pm \\
0.03\end{array}$ & $\begin{array}{c}52.72 \pm \\
0.02\end{array}$ & $\begin{array}{c}20.56 \pm \\
3.58\end{array}$ & $\begin{array}{c}83.2 \pm \\
14.4\end{array}$ & $\begin{array}{c}14.62 \pm \\
0.27\end{array}$ & $\begin{array}{c}2.441 \pm \\
0.002\end{array}$ & $\begin{array}{c}1.056 \pm \\
0.001\end{array}$ & $\begin{array}{c}1.779 \pm \\
0.348\end{array}$ \\
\hline
\end{tabular}

Table 7. Different physicochemical and nutritional analysis of fruit in syrup for each mango varieties.

\begin{tabular}{ccccccccccccc}
\hline & pH & SDE & $\begin{array}{c}\text { Titratable } \\
\text { acidity }\end{array}$ & & Colour & & Dry matter & Energy value & Vitamin C \\
& - & $\mathrm{g} / 100 \mathrm{~g}$ & $\mathrm{~g} / 100 \mathrm{~g}$ & $\mathrm{~L}$ & $\mathrm{a}$ & $\mathrm{b}$ & $\mathrm{g} / 100 \mathrm{~g}$ & $\mathrm{kcal} / 100 \mathrm{~g}$ & $\mathrm{mg} / 100 \mathrm{~g}$ & \\
\hline Bassignac & $4.11 \pm 0.00$ & $20.18 \pm 0.00$ & $0.25 \pm 0.00$ & $51.29 \pm 0.07$ & $2.73 \pm 0.09$ & $32.74 \pm 0.05$ & $26.59 \pm 4.75$ & $107.3 \pm 19.1$ & $3.60 \pm 0.39$ \\
Green & $4.00 \pm 0.00$ & $20.88 \pm 0.00$ & $0.36 \pm 0.01$ & $51.92 \pm 0.03$ & $1.48 \pm 0.16$ & $30.47 \pm 0.37$ & $22.86 \pm 0.02$ & $95.0 \pm 0.4$ & $10.31 \pm 0.00$ \\
Julie & $4.32 \pm 0.00$ & $20.76 \pm 0.00$ & $0.18 \pm 0.01$ & $54.15 \pm 0.08$ & $3.31 \pm 0.14$ & $37.39 \pm 0.09$ & $23.66 \pm 0.07$ & $95.7 \pm 0.3$ & $2.57 \pm 0.00$ \\
Moussache & $4.53 \pm 0.00$ & $20.61 \pm 0.00$ & $0.14 \pm 0.00$ & $54.92 \pm 0.25$ & $0.26 \pm 0.01$ & $33.40 \pm 0.05$ & $22.95 \pm 0.09$ & $94.1 \pm 0.4$ & $2.49 \pm 0.13$ \\
\hline
\end{tabular}

already published [14] [15]. Finally, with an average of $17.66 \mathrm{mg} / 100 \mathrm{~g}$ of vitamin C, values found in literature [15]-[17], mangoes supply $25 \mathrm{~g} / 100 \mathrm{~g}$ of recommended daily intake of World Health Organization (WHO).

We finally proposed three processing abilities for each mango variety. Mango puree is an intermediate food product. It could be proposed as a raw material for industries using fruit pulp of finished products such as jams, drinks, pastries, etc., but also to the catering and the health sector. Frozen mango cheeks could be proposed to consumers as a finished product or as intermediate food product. Canned mangos correspond to a finished product that could be used by consumers, bakers and restaurateurs. These three processes allow to have raw materials available throughout the year, regardless of the fruit crop cycle. The freezing process of mango cheeks allows to preserve the nutritional and physicochemical fresh fruit characteristics. But this process had a major drawback. The cheek texture after thawing drastically changes. The Green variety had a high transformation yield, with a high cheek caliber and insignificant texture changes. This was the variety most suitable for this transformation process. This variety has a high rate fibre which could explain the better performance of the cheeks frozen after thawing. Technological solutions must be necessarily introduced for a production of frozen mango cheeks ensuring the maintenance of the texture. The use of less mature fruits before the consumption stage would be a possible solution to this problem. This would facilitate more fruit cutting and peeling and therefore would increase the yield of production. The transformation of varieties studied in frozen mashing is also possible. The selection of one or the other varieties will depend on the applications envisaged for the finished product. Indeed the textural properties of purees obtained depended on the variety. The Moussache variety was less suitable for this type of transformation because it yielded lower production. Transformation in the forms of fruit purees and frozen cheeks preserve the nutrients of the fruit. Consumption possible throughout the year can meet the WHO recommendations that encourage increased consumption of fruits and vegetables. The transformation of varieties studied in fruit syrup is also possible. The Moussache variety was less suitable for this type of transformation because it yielded lower production. The best yields were observed for Julie and Green varieties. We observed losses in vitamin C and an important Maillard reaction during the process. These two points are normal in such a technological process and are extensively described in the literature. Technological solutions must still be found to reduce the cooking value applied to the product during the heat treatment. For instance, a reduction of the scale heat treatment could be considered. An acidification of the product with citric acid would eventually be considered to reduce the sterilizing value applied, but it may alter the taste of the 
product. The use of antioxidants, such as ascorbic acid could also be considered to reduce the browning phenomena and increase the vitamin $\mathrm{C}$ content of the finished product. In particular, ohmic heating and high pressures occur today as an alternative to pasteurization. Ohmic heating consist in high temperature during short time (process HTST, High Temperature Short Time) and high pressures bursts microbial cells. Both techniques would thus preserve the original taste of the fruit.

\section{Conclusion}

This study is the first to investigate varietal characterization of four mangoes in Martinique. This is the first time that such a study is conducted. Mango is an energy fruit. Varieties that were studied in Martinique are sources of vitamin $\mathrm{C}$, rich in polyphenols, with interesting total carotenoids content. This study has established for each variety studied, a fact sheet with the physicochemical, sensory and nutritional properties, as well as the data in terms of post-harvest storage (ripening) and production (yield, size, aptitude). These sheets can be used both by local producers, who have now a better knowledge of the different varieties and their conditions of post-harvest conservation, and by industrials wishing to use this raw material in their plant. This work is especially helpful for optimal management in mango harvesting within a contrasted territory. Moreover, knowledge of the characteristics of mangoes in Martinique has been improved, allowing the ripening stage to be optimized for each variety.

\section{Acknowledgements}

We would like to thanks the Regional Council of Martinique (F.W.I.) and the FEDER for its financial support. Producers and SOCOPMA who provide fruits are also greatly thanked. Ms Carolyn Milienne who provided language help is also thanked.

\section{References}

[1] Morton, J. (1987) Fruits of Warm Climates. J.F. Morton, Miami, Chapter Mango Mangifera indica L.

[2] Mitra, S.K. and Baldwin, E.A. (1997) Mango. In: Mitra, S., Ed., Postharvest Physiology and Storage of Tropical and Subtropical Fruits, CAB International, Wallingford, 85-122.

[3] Bender, R.J., Brecht, J.K. and Sargent, S.A. (1995) Inhibition of Ethylene Production in Mango Fruit by Elevated $\mathrm{CO}_{2}$ and Recovery during Subsequent Air Storage. Proceedings of the Florida State Horticultural Society, 108, 279-285.

[4] Gholap, A.S., Bandyopadhyay, C. and Nadkarni, G.B. (1986) Aroma Development in Mango Fruit. Journal of Food Biochemistry, 10, 217-229. http://dx.doi.org/10.1111/j.1745-4514.1986.tb00101.x

[5] Bender, R.J., Brecht, J.K., Baldwin, E. and Malundo, T. (1997) Effects of Controlled Atmosphere Storage on Aroma Volatiles of "Tommy Atkins” Mangoes. In: Kader, A.A., Ed., Proceedings of the Seventh International Controlled Atmosphere Research Conference, Vol. 3, Calif, 13-18 July 1997, 82.

[6] Lakshminarayana, S. (1980) Mango. In: Nagy, S. and Shaw, P.E., Eds., Tropical and Subtropical Fruits; Composition, properties and Uses, AVI, Westport, 15-22.

[7] Kumbhar, B.K. (1992) Processing of Mango in the Industry. Indian Food Industry, 12, 33-36.

[8] Ulloa, J.A., Escalona, H. and Diaz, L. (2008) Colour Behaviour on Mango Slices Self-Stabilized in Glass Jars by Hurdle Technology during Storage. African Journal of Biotechnology, 7, 487-98.

[9] Chauhan, O.P., Raju, P.S., Dasgupta, R.S., Shylaja, R., Sudhakar, R. and Bawa, A.S. (2006) Modified/Controlled Atmosphere Storage of Minimally Processed Mango Slices. American Journal of food Technology, 1, 105-116. http://dx.doi.org/10.3923/ajft.2006.105.116

[10] Vasquez-Caicedo, A.L., Neidhart, S., Pathomrungsiyounggul, P., Wiriyacharee, P., Chattrakul, A., Sruamsiri, P., Manochai, P., Bangerth, F. and Carle, R. (2002) Physical, Chemical and Sensory Properties of Nine Mango Cultivars and Evaluation of Their Technological and Nutritional Potential. Sustaining Food Security and Managing Natural Resources in Southeast Asia Symposium, Chiang Mai, 8-11 January 2002, 1-13.

[11] Georgé, S., Brat, P., Alter, P. and Amiot, M.J. (2005) Rapid Determination of Polyphenols and Vitamin C in PlantDerived Products. Journal of Agricultural and Food Chemistry, 53, 1370-1373. http://dx.doi.org/10.1021/jf048396b

[12] Tovar, B., Ibarra, L.I., Garcia, H.S. and Mata, M. (2000) Some Compositional Changes in Kent Mango Slices during Storage. Journal of Applied Horticulture, 2, 10-14. 
[13] Brat, P., Georgé, S., Bellamy, A., Du Chaffaut, L., Scalbert, A., Mennen, L., Arnault, N. and Amiot, M.J. (2006) Daily Polyphenol Intake in France from Fruit and Vegetables. Journal of Nutrition, 136, 2368-2373.

[14] Mercadante, A.Z. and Rodriguez-Amaya, D.B. (1998) Effects of Ripening, Cultivar Differences, and Processing on the Carotenoid Composition of Mango. Journal of Agricultural and Food Chemistry, 46, 128-130. http://dx.doi.org/10.1021/jf9702860

[15] Sogi, D.S., Siddiq, M., Roidoung, S. and Dolan, K.D. (2012) Total Phenolics, Carotenoids, Ascorbic Acid, and Antioxidant Properties of Fresh-Cut Mango (Mangifera indica L., cv. Tommy Atkin) as Affected by Infrared Heat Treatment. Journal of Food Science, 77, 1197-1202. http://dx.doi.org/10.1111/j.1750-3841.2012.02933.x

[16] Spencer, J.L., Morris, M.P. and Kennard, W.C. (1956) Vitamin C Concentration in Developing and Mature Fruits of Mango. Plant Physiology, 31, 79-80. http://dx.doi.org/10.1104/pp.31.1.79

[17] Sulaiman, S.F. and Ooi, K.L. (2012) Polyphenolic and Vitamin C Contents and Antioxidant Activities of Aqueous Extracts from Mature-Green and Ripe Fruit Fleshes of Mangifera sp. Journal of Agricultural and Food Chemistry, 60, 11832-11838. http://dx.doi.org/10.1021/jf303736h 
Scientific Research Publishing (SCIRP) is one of the largest Open Access journal publishers. It is currently publishing more than 200 open access, online, peer-reviewed journals covering a wide range of academic disciplines. SCIRP serves the worldwide academic communities and contributes to the progress and application of science with its publication.

Other selected journals from SCIRP are listed as below. Submit your manuscript to us via either submit@scirp.org or Online Submission Portal.
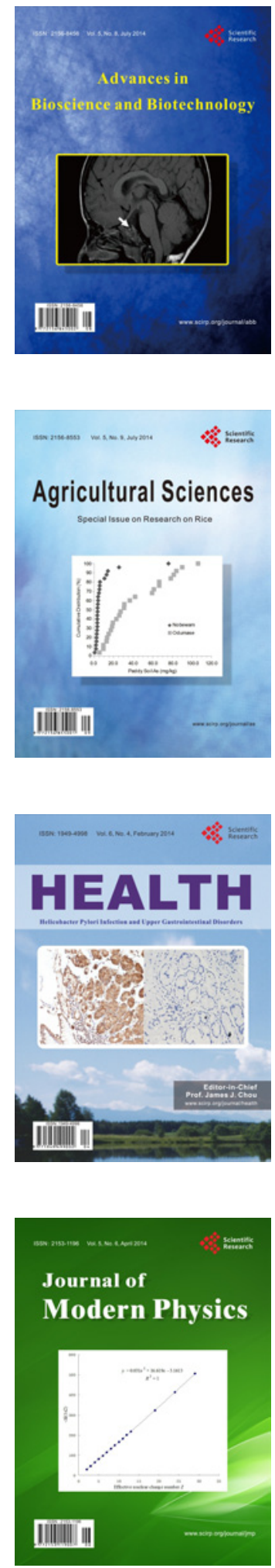
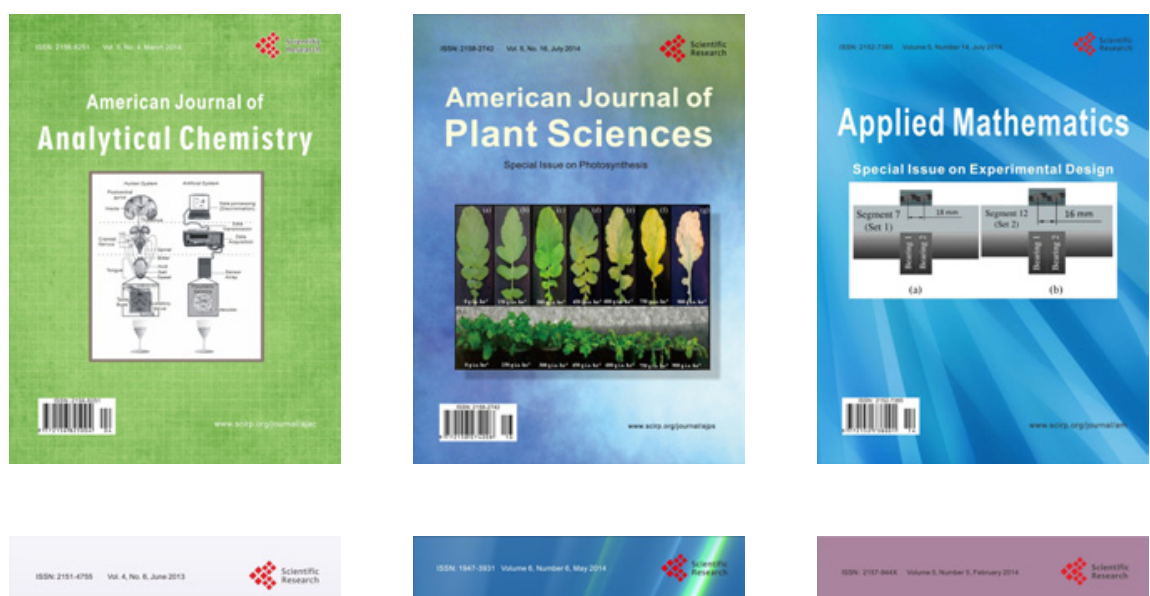

Creative Education
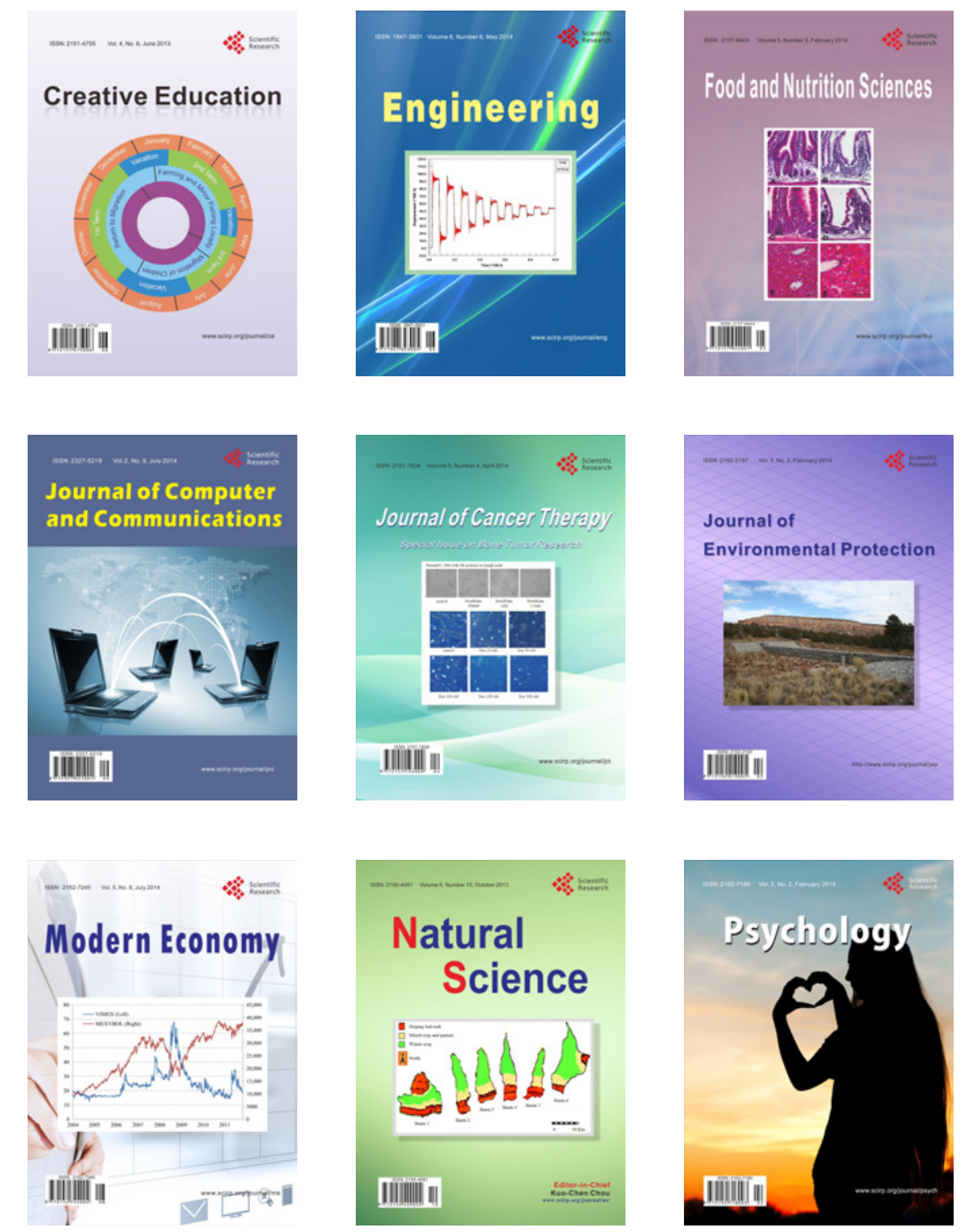